\title{
The influence of pre-lamb shearing on lamb birthweight and survival
}

\author{
S.T. MORRIS ${ }^{1}$, P.R. KENYON ${ }^{1}$, D.L. BURNHAM ${ }^{1}$ and S.N. McCUTCHEON ${ }^{2}$ \\ ${ }^{1}$ Institute of Veterinary, Animal \& Biomedical Sciences, Massey University, Palmerston North \\ ${ }^{2}$ Vice Chancellors Office, Massey University, Palmerston North
}

\begin{abstract}
Shearing ewes in mid pregnancy can provide farmers with management and financial advantages. Six experiments conducted at Massey University have collectively shown that shearing ewes at this time can increase lamb birthweight by up to $1.0 \mathrm{~kg}$. When comparisons were made across studies, there was a strong negative relationship between size of the response and the birthweight of control lambs (those from unshorn ewes). The best time to shear ewes to gain a maximum response is likely to be pregnancy day 50 to 100 . In a large field trial involving 1002 twin-born lambs, there was a 3\% reduction in mortality rate in lambs born to ewes shorn at pregnancy day 67 compared with those lambs born to unshorn ewes (i.e., mortality rates of 15 vs $18 \%$ ). Pre-lamb shearing offers real advantages to farmers wishing to increase lamb survival at birth.
\end{abstract}

Keywords: ewes, lamb birthweight, lamb mortality, mid-pregnancy shearing

\section{Introduction}

Each year in New Zealand approximately four million lambs (15\% of newborn lambs) - almost all of which are inherently viable at birth - die in the first 3 weeks of life. Aside from the tremendous wastage, this loss has important animal welfare implications and is an agricultural practice which could lead to the imposition of non-tariff trade barriers.

The optimum birthweight range for maximum lamb survival is $3.5-5.5 \mathrm{~kg}$ (Dalton et al. 1980). These authors studied the relationship between birthweight and mortality over 7 years in 10000 lambs of 10 breeds and crosses. Mortality was highest at the extremes of the birthweight range. Deaths associated with low birthweights, i.e., less than $3.5 \mathrm{~kg}$ (especially in twinborn lambs), are primarily due to starvation-exposure (McCutcheon et al. 1981) while lambs born above 5.5 $\mathrm{kg}$ (usually single-born) are at risk of death from dystocia (difficult births). Increasing lamb birthweight to improve new-born lamb survival, particularly in twins, is a desirable management goal for our sheep flocks.
However, it is extremely difficult to alter lamb birthweight by nutritional manipulation of the ewe during late gestation because of the dam's ability to buffer the fetus against such changes using her own body reserves. Furthermore, because newborns of both high and low birthweight are at risk, simply changing the average birthweight is unlikely to reduce mortality (e.g., increasing average birthweight may increase the survival of small twins but it will concurrently reduce the survival of large single-born lambs). Therefore, the solution lies in developing methods which allow selective manipulation of the growth patterns of fetuses destined to be born as singles or twins.

\section{Pre-lamb shearing}

Shearing ewes in mid pregnancy (i.e., pre-lamb shearing in June or July depending on mating dates) can provide farmers with both management and financial advantages (Dabiri et al. 1994; Parker \& Gray 1989; Parker 1992). Direct financial advantages can arise from: pre-lamb shorn wool which is of higher quality (better colour and greater strength due to wool harvesting occurring at the optimum time in relation to the pattern of fibre growth); reduced overhead charges for seasonal finance; lower shearing costs through the elimination of prelamb crutching; and less wool lost through ewe deaths over the lambing period. Management advantages include an improved spread of labour requirements for sheep work, a reduction in ewes lost from becoming cast, and an increased flexibility with operations such as weaning and the selling of wet/dry ewes.

The major disadvantage of a pre-lamb shear is the potentially high ewe losses following shearing during cold, windy and wet weather. Leaving a greater depth of wool on the sheep during fleece removal provides a practical and inexpensive means to reduce this risk. The use of a cover comb, which leaves a stubble depth of about $5 \mathrm{~mm}$ compared with $3 \mathrm{~mm}$ left by the standard comb (Dabiri et al. 1995), increases the insulation of the animal and reduces the risk associated with losing sheep after a winter shear. A further disadvantage often cited by farmers is the inability to supply an adequate level of pasture relative to the increased feed requirements of ewes following shearing. However, our research has not been able to measure significant 
increases in feed intake in newly shorn pregnant ewes compared with unshorn pregnant ewes following shearing at pregnancy day 114 (P114) (Dabiri et al. 1995), at P115 when newly shorn and unshorn ewes grazed at various pasture heights (Husain et al. 1997), at P91 (Parker et al. 1991) or at P70 (unpublished data). An increase in feed intake has been measured in only one trial and that did not occur until 23 days after shearing on P118 of pregnancy (Dabiri et al. 1996). The general lack of a feed intake response may reflect the fact that the developing fetus impinges on the ewe's digestive tract and limits opportunities to increase feed intake (a situation which does not exist in dry animals where intake responses to shearing are more common).

\section{Review of trials}

Several studies in the United Kingdom have demonstrated an increase in lamb birthweight following shearing of ewes during pregnancy (Austin \& Young 1977; Symonds et al. 1986; Vipond et al. 1987). Birthweight responses in housed ewes in the United Kingdom are greatest when shearing occurs relatively early in pregnancy, perhaps reflecting both an effect on placental development and the greater time available for altered fetal growth before the lamb is born. This situation could arise in ewes which are cold stressed because of shearing, as in our New Zealand outdoor grazing conditions, given that under these circumstances maternal cold stress could alter nutrient supply to the fetus.

The objective of recent research at Massey University has been to determine whether shearing ewes in mid-pregnancy leads to a greater increase in fetal growth, as measured by birthweight, than the latepregnancy shearing of earlier New Zealand studies. This research consisted of a series of five outdoor trials over 4 years (1995-98) and at two locations (Manawatu and Wairarapa), and one indoor trial (1997). All of the trials were conducted with mixed age Border Leicester $\times$ Romney or Romney ewes. In the first experiment in 1995, there was a differential effect of pregnancy shearing on the birthweights of single and twin lambs. Thus, while shearing had no effect on the birthweights of singles, those of twins increased progressively with shearing earlier in pregnancy, reaching a maximum of $0.7 \mathrm{~kg}$ (per lamb) in ewes shorn at P70 (Morris \& McCutcheon 1997). Although birthweight responses of 0 to $1.0 \mathrm{~kg}$ in twin lambs were measured in the subsequent series of five trials, these were not consistent with respect to the magnitude of the response or its occurrence in singles versus twins.

Method of shearing (using a standard or cover comb) did not significantly affect the birthweight response. Therefore it is suggested that the cover comb be used whenever pre-lamb shearing occurs, in order to decrease the potential risk of losses from hypothermia in newly shorn sheep (Dabiri et al. 1995).

The exact time of shearing to maximise the birthweight response needs to identified. Only in the first trial was there a relationship between time of shearing and birthweight response, i.e., the earlier ewes were shorn in pregnancy the greater the response. No ewes have been shorn before day 50 of pregnancy, however our results suggest a response should occur in the interval between P50 and P100. This makes sense in that ewes shorn in this period (P50-P100) would have a greater opportunity to respond to the shearing effect than those shorn after P100 around which time placental weights peak. It may be that placental growth over this period also interacts with potential fetal growth, which is primarily exhibited in the last 50 days of pregnancy.

When the shearing response across all trials was compared (Figure 1), the effect was greatest when the birthweights of control lambs (those born to unshorn ewes) were lowest in both singles and twins (Kenyon et al. 1999). We conclude that responses to midpregnancy shearing (P50-P100) are likely to be greatest when lamb birthweights are destined to be low (i.e., when the control fetuses are destined not to achieve their genetic potential for growth). This will commonly occur when a substantial maternal constraint is operating, most probably because of sub-optimal ewe feeding over the summer/autumn period.

Figure 1 Birthweight response to mid-pregnancy shearing (singles - hollow points, twins - shaded points) as a function of the birthweight of control lambs (each point represents a separate trial or treatment (shearing date) within a trial). (Source: Kenyon et al. 1999).

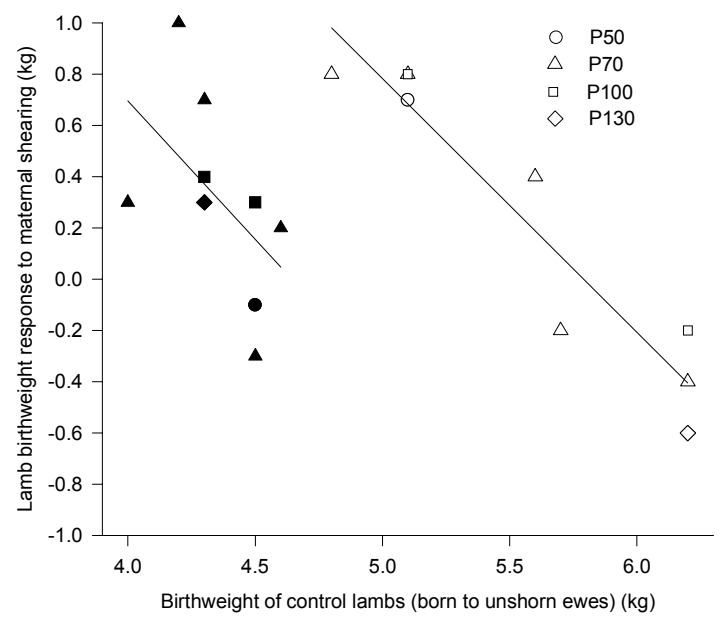




\section{Lamb mortality}

Research shows that early-pregnancy shearing can selectively increase the birthweights of twin lambs, but to be of benefit this needs to translate into reduced lamb mortality. In our earlier trials, the effect on lamb mortality was not tested because of the low ewe numbers used in the trials. However, when the results of these trials are applied to the data of Dalton et al. (1980), the potential benefits of early pregnancy shearing can be estimated. Dalton et al. (1980) classified 2630 multipleborn lambs according to birthweight ranges (column 1, Table 1), number born in each range (column 2), and $\%$ survival. Using these figures, calculations can be made of the \% mortality as (100-\% survival) (column 3 ) and hence actual number of lambs dead (number born $\times \%$ mortality) in each birthweight group (column 4). Overall, $593(23 \%)$ of the 2630 multiple-born lambs did not survive to weaning.

Table 1 Actual mortality of multiple-born lambs by birthweight range (column 4) and predicted mortality (column 6) if birthweights increased by $0.5 \mathrm{~kg}$ due to early-pregnancy shearing. Columns 1-4 adapted from Dalton et al. (1980).

\begin{tabular}{|c|c|c|c|c|c|}
\hline $\begin{array}{c}\text { (1) } \\
\text { Actual BW } \\
\text { Range (kg) }\end{array}$ & $\begin{array}{l}(2) \\
\text { No. }\end{array}$ & $\begin{array}{c}(3) \\
\text { Mortality } \\
(\%)\end{array}$ & $\begin{array}{c}\text { (4) } \\
\text { Actual } \\
\text { Deaths }\end{array}$ & $\begin{array}{c}(5) \\
\text { New } \\
\text { Distribution }\end{array}$ & $\begin{array}{c}\text { (6) } \\
\text { Predicted } \\
\text { Deaths }\end{array}$ \\
\hline$<2.0$ & 49 & 77.6 & 38 & - & - \\
\hline $2.0-2.5$ & 162 & 46.9 & 76 & 49 & 23 \\
\hline $2.5-3.0$ & 325 & 28.6 & 93 & 162 & 46 \\
\hline $3.0-3.5$ & 674 & 22.0 & 148 & 325 & 72 \\
\hline $3.5-4.0$ & 709 & 18.2 & 129 & 674 & 123 \\
\hline $4.0-4.5$ & 460 & 14.3 & 66 & 709 & 101 \\
\hline $4.5-5.0$ & 194 & 17.5 & 34 & 460 & 81 \\
\hline$>5.0$ & -57 & 15.8 & -9 & _251 & _40 \\
\hline Totals & 2630 & & 593 & 2630 & 486 \\
\hline
\end{tabular}

If it is assumed, based on data from our trials reported above, that early-pregnancy shearing increases birthweight of multiple lambs by (a conservative) 0.5 $\mathrm{kg}$, this has the effect of "moving" each lamb up one birthweight category (e.g., lambs which would have been in the $2.0-2.5 \mathrm{~kg}$ range are now in the $2.5-3.0 \mathrm{~kg}$ range). Lamb mortalities (column 6) can then be recalculated as the product of the mortality rate for a particular birthweight range (column 3 ) and the number of lambs now in that range (column 5). This shows that expected deaths are reduced from 593 to 486 lambs (i.e., a reduction of 107 multiples per 2630 born or 40 lambs per 1000 born). Put another way, mortality is reduced from $23 \%(593 / 2630)$ to $18 \%(486 / 2630)$.

This estimate has been validated subsequently in a field trial involving 1300 twin-bearing ewes at Riverside Farm, Wairarapa in 1998, where the mortality of lambs born to ewes shorn (using a cover comb) at P67 or P130 of pregnancy versus unshorn ewes was investigated. The ewes were mixed age Romney ewes weighing 54.4 $\mathrm{kg}$ at mating on 9 April to Suffolk rams. Pregnancy diagnosis was conducted on P64 (12 June being 64 days since mid-point of the first cycle of mating) and ewes (average liveweight $64.0 \mathrm{~kg}$ ) were randomly allocated to the three treatments. After a second pregnancy diagnosis on P83 (1 July), 511 first-cycle twin-bearing ewes were retained in the experiment. The ewes were run as one mob until set stocking (allocated randomly by treatment group to six paddocks) immediately before lambing, at nine ewes/ha, where they remained throughout the experiment. At set stocking ewes weighed $67.0 \pm 0.6(\mathrm{SEM}), 67.3 \pm 0.6$ and $67.7 \pm$ $0.6 \mathrm{~kg}$, respectively. Ewe liveweight and condition score during lactation were not influenced by shearing treatment. Lamb liveweights were analysed using analysis of variance to test the effects of shearing date, lamb sex and paddock. The proportion of lamb deaths was analysed as a binomial trait using the SAS procedure for categorical data modelling (SAS 1985).

Shearing at day P67 and P130 of pregnancy increased lamb birthweight by 0.3 and $0.2 \mathrm{~kg}$, respectively (Table 2 ). This difference remained and increased to 1.1 and $0.8 \mathrm{~kg}$ at weaning. Associated with this increase in lamb birthweight was a $3 \%$ decrease in lamb mortality (from 18 to $15 \%$ ) for twin lambs born to ewes shorn at P67 of pregnancy compared to twin lambs born to unshorn ewes. (For a 3000 ewe flock with a $140 \%$ lambing and $90 \%$ of ewes rearing a lamb this equates to an extra $\$ 3600$ in sales income if lambs are valued at $\$ 40 /$ head). This is broadly consistent with the results of the simulation exercise described above, though it is not clear why mortality was not reduced in lambs born to ewes shorn at P130.

Table 2 Effects of shearing at pregnancy day P67 or P130 on lamb birthweight, weaning weight and mortality rates.

\begin{tabular}{lccc}
\hline & Unshorn & Shorn P67 & Shorn P130 \\
\hline Lambs born & 351 & 324 & 327 \\
Birthweight $(\mathrm{kg})$ & $4.5 \pm 0.1^{\mathrm{a}}$ & $4.8 \pm 0.1^{\mathrm{b}}$ & $4.7 \pm 0.1^{\mathrm{b}}$ \\
Weaning weight $(\mathrm{kg})$ & $24.4 \pm 0.2^{\mathrm{a}}$ & $25.5 \pm 0.2^{\mathrm{b}}$ & $25.2 \pm 0.2^{\mathrm{b}}$ \\
Lamb deaths & 64 & 48 & 57 \\
Mortality rate $(\%)$ & 18.2 & 14.8 & 17.4 \\
\hline ab Means within rows with different superscripts are significantly \\
\begin{tabular}{l} 
different $(\mathrm{P}<0.05)$ \\
\hline
\end{tabular}
\end{tabular}

\section{Conclusions}

The results of a series of Massey University trials indicate that shearing ewes during pregnancy (P50P100) can increase lamb birthweight. Producers who 
use this practice are more likely to get a response in years when conditions result in less than optimum lamb birthweights. Pre-lamb shearing does not affect the subsequent growth of lambs and the increased birthweight can lead to reduced mortality rates in twin-born lambs. However, the circumstances which lead to optimum birthweights in single- and twin-bearing ewes, and hence the question of whether these groups need to be identified by scanning and treated separately, requires further study.

\section{ACKNOWLEDGEMENTS}

The authors thank Wools of NZ and the Riverside Farm Research Fund for funding support. We also thank Mr Neil Kilmister, Manager of Riverside Farm, for assistance with collection of field data.

\section{REFERENCES}

Austin, A.R.; Young, N.E. 1977. The effects of shearing pregnant ewes on lamb birth weights. The veterinary record 100: 527-529.

Dabiri, N.; Parker, W.J.; Morris, S.T.; McCutcheon, S.N. 1994. Effects of pre-lamb and conventional full-wool shearing on the productivity of ewes. Proceedings of the New Zealand Society of Animal Production 54: 223-226.

Dabiri, N.; Morris, S.T.; Parker, W.J.; McCutcheon, S.N.; Wickham, G.A. 1995. Productivity and cold resistance in ewes pre-lamb shorn by standard or cover comb. Australian journal of agricultural research 46: 721-732.

Dabiri, N.; Morris, S.T.; Wallentine, M.; McCutcheon, S.N.; Parker, W.J.; Wickham, G.A. 1996. Effects of pre-lamb shearing on feed intake and associated productivity of May- and August-lambing ewes. New Zealand journal of agricultural research 38: 53-62.

Dalton, D.C.; Knight, T.W.; Johnson, D.L. 1980. Lamb survival in sheep breeds on New Zealand hill country. New Zealand journal of agricultural research 39: 53-62.
Husain, M.H.; Morris, S.T.; McCutcheon, S.N.; Parker W.J. 1997. Pasture management to minimise the detrimental effects of pre-lamb shearing. New Zealand journal of agricultural research 40: 489496.

Kenyon,P.R.; Morris, S.T.; Revell, D.K.; McCutcheon, S.N. 1999. Improving lamb birthweight through midto late-pregnancy shearing: a review of recent studies. Proceedings of the New Zealand Society of Animal Production 59: 70-72.

McCutcheon, S.N.; Holmes, C.W.; McDonald, M.F. 1981. The starvation-exposure syndrome and neonatal lamb mortality: a review. Proceedings of the New Zealand Society of Animal Production 41: 209-217.

Morris, S.T.; McCutcheon, S.N. 1997. Selective enhancement of growth in twin foetuses by shearing ewes in early gestation. Animal science 65: 105110.

Parker, W.J.; Morris, S.T.; McCutcheon, S.N. 1991. Wool production and feed intake in unmated and mated Border Leicester $\times$ Romney crossbred ewes shorn in July or November. New Zealand journal of agricultural research 34: 427-437.

Parker, W.J. 1992. Managing a pre-lamb shearing policy. Proceedings of the Central Districts Sheep and Beef Cattle Farmers' Conference 1: 65-69.

Parker, W.J.; Gray, D.I. 1989. The effect of alternative ewe shearing policies on sheep performance, cashflow and profit. Wool 12: 16-19.

SAS 1985. SAS Users' guide, version 5 edition. Cary, N.C., USA, SAS Institute Inc.

Symonds, M.E.; Bryant, M.J.; Lomax, M.A. 1986. The effect of shearing on the energy metabolism of the pregnant ewe. British journal of nutrition 56: 635643.

Vipond, J.E.; King, M.E.; Inglis, D.M.; Hunter, E.A. 1987. The effect of winter shearing of housed pregnant ewes on food intake and animal performance. Animal production 45: 211-221. 